\title{
Depth-gradient structure of the demersal fish community on the continental shelf and upper slope off Sendai Bay, Japan
}

\author{
Toshihiko Fujita*, Tadashi Inada, Yoshio Ishito \\ Tohoku National Fisheries Research Institute, Hachinohe, Shimo-mekurakubo 25-259, Same, Hachinohe 031, Japan
}

\begin{abstract}
The demersal fish community was examined at 15 sites on the continental shelf and upper slope off Sendai Bay, Japan, from 1989 to 1991. The community structure was analyzed along the depth gradient (ca 150 to $450 \mathrm{~m}$ ). The species compositions at the shallowest site and the deepest site were different from the other sites. The depth range covered not only an upper slope community but also the shallower shelf community and the deeper slope community. The species composition varied annually at each site, but some stable species composition was observed in intermediate-depth waters (ca 240 to $370 \mathrm{~m}$ ). The intrmediate depths were considered to be center depths of the distribution of the uppermost slope community which was characterized by the dominance of Theragra chalcogramma and Gadus macrocephalus, high biomass and low species diversity. Biomass was maximum and species diversity was minimum at the intermediate depths, and gradually changed with depth toward the other communities. The transition depths were located on both sides of the center depths of the upper slope community, where the percentage by biomass of the 2 dominant fish species was low and/or variable and the species composition was heterogeneous compared to the center depths.
\end{abstract}

KEY WORDS: Demersal fish community - Biomass - Species diversity - Depth zonation Persistence Theragra chalcogramma . Gadus macrocephalus

\section{INTRODUCTION}

Fish communities have been intensively studied in a variety of habitats such as fresh water, coral reefs and marine coastal regions, especially with regard to the organization of community structure (see reviews by Sale 1980, Werner 1984, 1986). Recent ichthyofaunal studies have dealt with demersal communities on the continental shelf and slope (e.g. May \& Blaber 1989 , Blaber et al. 1990, Bianchi 1991, 1992a, b, Merrett et al. 1991a, b, Macpherson \& Gordoa 1992, Merrett 1992, Fujita et al. 1993), and many of the studies classified the fish assemblages and revealed some depth zonation. However, relatively few data have been obtained which allow discussion of the structural patterns of communities in these offshore habitats (Fujita 1993).

\footnotetext{
- Present address: National Science Museum, Tokyo, Hyakunin-cho 3-23-1, Shinjuku, Tokyo 169, Japan
}

Demersal fishes on the continental shelf and upper slope off Sendai Bay, Japan, have been surveyed since 1988 by the Tohoku National Fisheries Research Institute, Hachinohe, to investigate fisheries resources in the area. Using a part of the data, Fujita et al. (1993) classified 3 community types represented by each of 3 numerically dominant gadiform fish species, Theragra chalcogramma, Gadus macrocephalus and Physiculus maximowiczi. The shelf community was dominated by $P$. maximowiczi, while the uppermost slope community, in which the biomass of the demersal fish community was very high, was dominated by T. chalcogramma and G. macrocephalus (Fujita et al. 1993). Another gadiform fish, Laemonema longipes, was known to be often dominant in the deeper waters (unpubl, data), and hence some depth zonation was recognized in this area.

This study presents results of otter trawl surveys of the demersal fishes off Sendai Bay encompassing the depths where Theragra chalcogramma and Gadus 
macrocephalus were dominant. We analyzed the trawl catch data obtained at 15 sites in 3 successive years in order to explore the depth-gradient structure of the demersal fish community and its annual variation. Our main objective was to interpret the zonation structure of the demersal fish community.

\section{MATERIALS AND METHODS}

Sampling. Trawling stations were established at 15 sites at water depths between 138 and $474 \mathrm{~m}$ off Sendai Bay (Fig. 1). Demersal fish were collected by the RV 'Shunyo Maru' of the National Research Institute of Far Sea Fisheries during every November from 1989 to 1991 (11 to 16 November 1989,9 to 15 November 1990 and 9 to 16 November 1991). Fish were captured using an otter trawl with a $59 \mathrm{~m}$ headrone, a $68 \mathrm{~m}$ groundrope, and a stretched mesh of $45 \mathrm{~mm}$ in. the cod end. Some small fishes, especially myctophids, may have passed through the mesh and not been quantitatively sampled. The sites were trawled

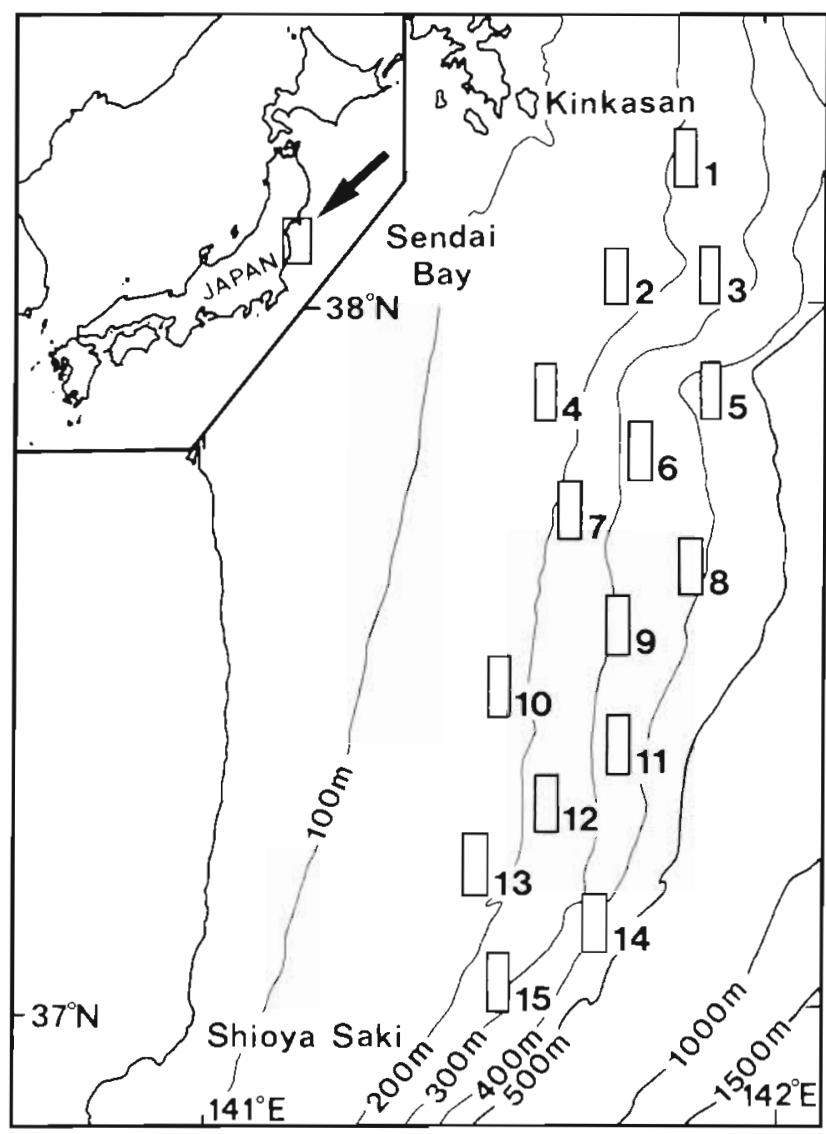

Fig. 1. Sampling sites off Sendai Bay, Japan. Open rectangles location of the otter trawl sampling; numerals indıcate site number. Trawling was carried out within each area of $9.3 x$ $3.7 \mathrm{~km}$ indicated by the rectangles during daylight between 08:00 and 17:00 h. Tows were about $30 \mathrm{~min}$ in duration (except for $50 \mathrm{~min}$ tows at Sites 6, 8 and 11 in 1990), timed from the settling of the net on the bottom to its retrieval time of the bottom, monitored acoustically. The mean towing speed was 3.7 knots $\left(6.9 \mathrm{~km} \mathrm{~h}^{-1}\right)$.

Most of the catches were sorted and identified to species level, and each species was counted and weighed separately on board. A part of the catches was frozen, and was identified and measured later in the laboratory. Myctophid fishes were mostly composed of Diaphus watasei but also included some unidentified species. These were difficult to separate by species and were pooled together and regarded as 1 taxon for the analysis. Because some fishes in the samples at Sites 3, 7 and 9 in 1989 were not counted, numerical data were not obtained for these samples. Fish density and biomass were estimated based on the trawled area $\left[81 \pm 16 \times 10^{3} \mathrm{~m}^{2}\right.$ (mean $\left.\left.\pm \mathrm{SD}\right)\right]$ which was calculated from the wingspread of the net and the towing distance. The average wingspread was acoustically measured to be $22.3 \mathrm{~m}$, and the towing distance was calculated from the ship movement while the net was on the bottom at each sampling site. Catchability coefficients of fishes were assumed to be 1 for all species, since we had no information about these coefficients.

Hydrographic stations were arranged on 4 line transects encompassing the area of the trawling stations (Fig. 2). Temperature and salinity were examined from the sea surface to the bottom using a M-STD (Alec Electronics Co., Ltd) on board the RV 'Wakataka Maru' of the Tohoku National Fisheries Research Institute, almost concurrently with the trawling (11 to 12 November 1989, 9 to 15 November 1990 and 9 to 12 November 1991). In 1991, hydrographic surveys were also carried out at most of the trawling stations and several additional stations.

Data analysis. We used cluster analysis and principal components analysis to identify patterns of species associations based on the trawl catch data in terms of biomass. Clustering by the group average method was executed for the similarity matrices of 15 site catches in each year. Similarity was calculated using the Morisita-Horn index $\hat{C}_{\lambda}$ (Morisita 1959, Horn 1966). Principal components analysis was applied to the 45 sample (15 sites $\times 3$ years) correlation matrix of 77 species. Before these analyses, biomass values were $\log (x+1)$-transformed. These multivariate analyses were executed by BASIC computer programs (Tanaka et al. 1984)

We measured numerical density, biomass, mean body weight per fish, and species diversity indices to investigate the community structure. As measures of species diversity, we used the number of species $(S)$, 
Fig. 2. Temperature and salinity of bottom waters in November 1991. Open circles arranged on 4 transects denote hydrographic stations. Hydrographic data were also obtained at the trawling stations indicated by numbers
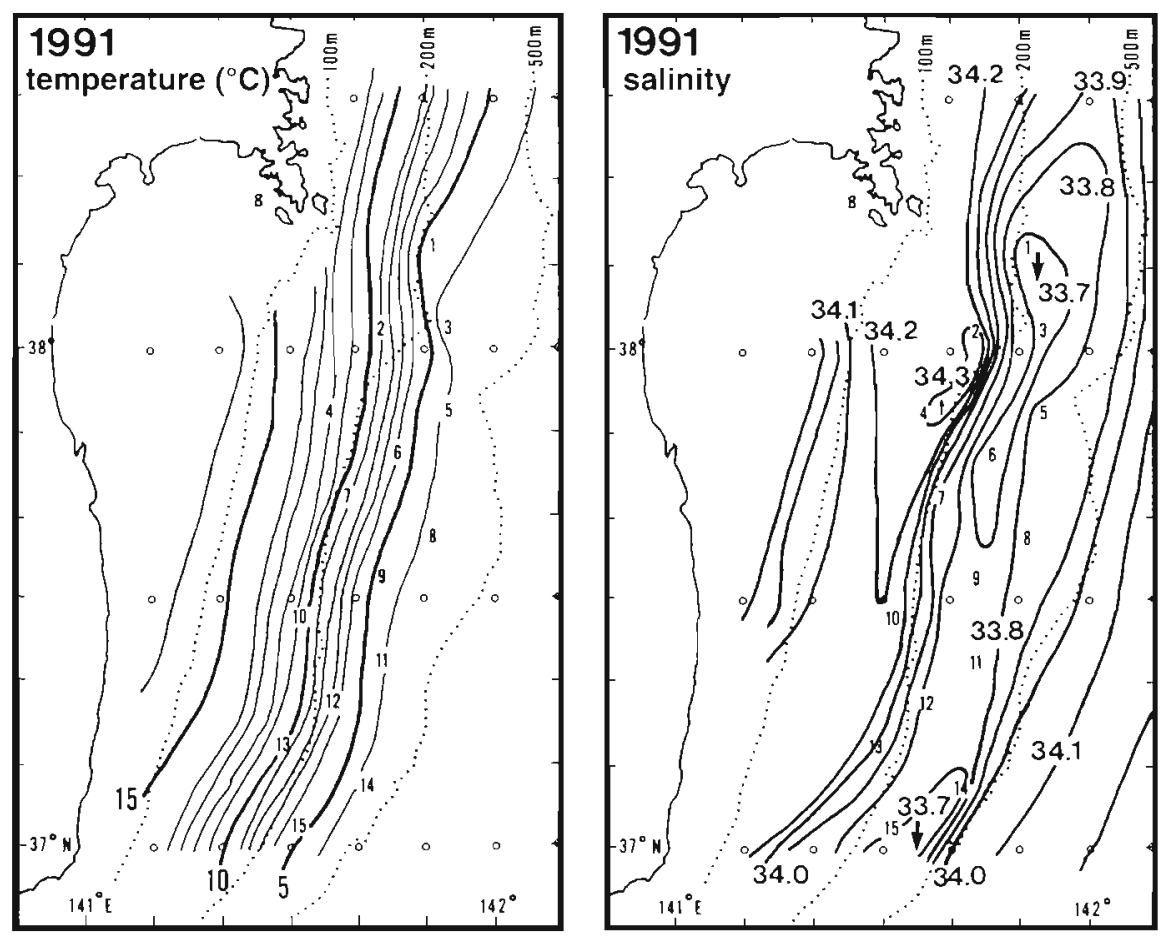

\section{RESULTS}

\section{Bottom environments}

Temperature and salinity of the bottom waters are shown in Figs. $2 \& 3$. Temperature decreased with increasing depth up to about $300 \mathrm{~m}$, and was homogeneous at $\mathrm{ca} 4^{\circ} \mathrm{C}$ below $300 \mathrm{~m}$. An intense decrease in temperature was observed at the depths between 200 and $250 \mathrm{~m}$ from $10-13^{\circ} \mathrm{C}$ to $\mathrm{ca} 6^{\circ} \mathrm{C}$. Although some annual differences were observed for salinity, lowsalinity $(<34.0)$ waters were usually found at depths between about 250 and $400 \mathrm{~m}$. Salinity was high and variable $(33.8$ to 34.4$)$ in shallow bottom waters $(<200 \mathrm{~m})$, whereas it was high and relatively homogeneous (34.0 to 34.3 ) in deep bottom waters (>500 m).

\section{Overall catch}

A total of 77 species $(6069 \mathrm{~kg})$ were collected in the study area off Sendai Bay from 1989 to 1991 (see Appendix). Table 1 gives a list of the most abundant species in the overall catch from 15 sites in each year. The gadid fishes Gadus macrocephalus and Theragra chalcogramma were the dominant members of the demersal fish community. Both species occurred at more than 11 out of the 15 sites in every year. Total biomass decreased from 2.5 to $1.0 \mathrm{~kg}$ per $1000 \mathrm{~m}^{2}$ through the study period. The decrease in biomass resulted pairs of the 3 censuses. 

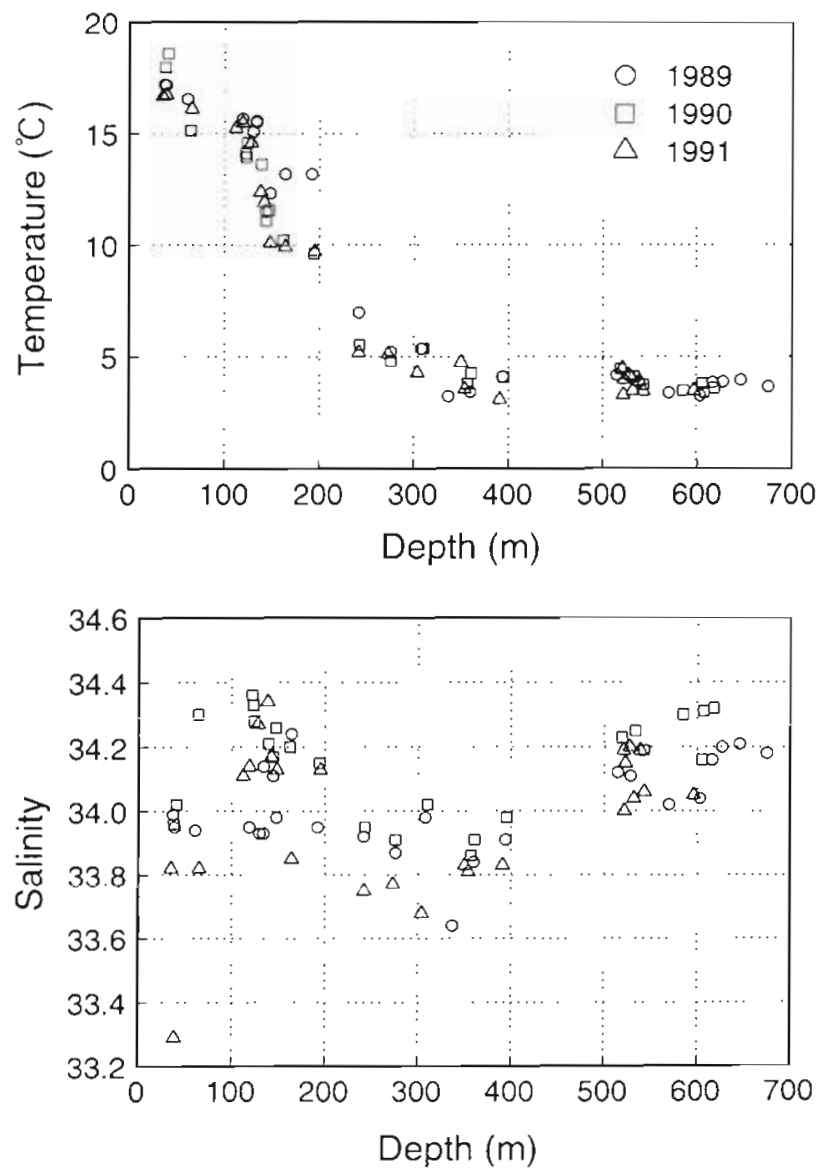

Fig. 3. Temperature and salinity of bottom waters along the depth gradient in November from 1989 to 1991

mainly from the decrease in the biomass of $G$. macrocephalus and $T$. chalcogramma. The 2 most abundant species remained at $81 \%$ of the overall catch in 1989 and 1990, and dropped to $60 \%$ in 1991. The other constantly abundant species were a morid, Physiculus maximowiczi, and a macrourid, Abyssicola macrochir. The remaining species made up a small and inconstant proportion of the catch.

\section{Depth patterns in species composition}

Principal components analysis revealed that some gradual change in species composition occurred along the depth gradient. Many sites were grouped together, but the deepest site (Site 5) was set apart in all years, especially by the 1 st axis, and several other sites were separated occasionally (Fig. 4). The first 2 principal components were significantly correlated with depth (Fig. 4, Table 2) The score of the 1st axis was greater in deeper water and remarkably well correlated with depth both in linear and quadratic regressions $(\mathrm{p}<$
0.001 for the pooled data from 3 years). The fit was better for the quadratic regression, but the 1st axis increased with increasing depth because the minimum value was observed at almost the shallowest depth High positive load on the 1st component was observed for the deeper-water species, e.g. Malacocottus zonurus, Lycodes hubbsi and Zestichthys tanakai, and high negative load for the shallower-water species, e.g. Hemitripterus villosus, Liparis tanakai and Dexistes rikuzenius. The score of the 2 nd axis was minimum in the intermediate depth around $300 \mathrm{~m}$, indicated by much better fit of the quadratic regression $(p<0.001$ for the pooled data from 3 years). High negative load on the 2nd component by Gadus macrocephalus and Theragra chalcogramma suggested that the 2 nd com-

Table 1. The 10 most abundant species in the overall catch by year. Biomass is given as the mean for 15 sites. Frequency: number of sites where each species occurred

\begin{tabular}{|c|c|c|c|}
\hline \multirow{2}{*}{$\begin{array}{r}\text { Species } \\
1989\end{array}$} & \multicolumn{2}{|c|}{$\begin{array}{l}\text { Biomass } \\
\mathrm{kg} \text { per } \\
1000 \mathrm{~m}^{2} \quad(\%)\end{array}$} & \multirow[t]{2}{*}{ Frequency } \\
\hline & & & \\
\hline 1 Gadus macrocephalus & 1.18 & $(48)$ & 12 \\
\hline 2 Theragra chalcogramma & 0.81 & (33) & 12 \\
\hline 3 Myctophidae spp. & 0.10 & (4) & 13 \\
\hline 4 Physiculus maximowiczi & 0.07 & (3) & 14 \\
\hline 5 Abyssicola macrochir & 0.05 & (2) & 7 \\
\hline 6 Scomber japonicus & 0.05 & (2) & 1 \\
\hline 7 Liparis tanakai & 0.04 & (2) & 7 \\
\hline 8 Oncorhynchus keta & 0.02 & (1) & 5 \\
\hline 9 Pterothrissus gissu & 0.02 & (1) & 9 \\
\hline 10 Laemonema longipes & 0.02 & (1) & 2 \\
\hline Total (47 species) & 2.47 & & \\
\hline \multicolumn{4}{|l|}{1990} \\
\hline 1 Theragra chalcogramma & 0.82 & $(55)$ & 14 \\
\hline 2 Gadus macrocephalus & 0.40 & (26) & 14 \\
\hline 3 Brama japonica & 0.07 & (5) & 9 \\
\hline 4 Physiculus maximowiczi & 0.05 & (3) & 13 \\
\hline 5 Abyssicola macrochir & 0.05 & (3) & 9 \\
\hline 6 Glossanodon semifasciatus & 0.02 & (1) & 4 \\
\hline 7 pterothrissus gissu & 0.01 & (1) & 10 \\
\hline 8 Liparis tanakai & 0.01 & (1) & 4 \\
\hline 9 Laemonema longipes & 0.01 & (1) & 2 \\
\hline 10 Stichaeus grigorjewi & 0.01 & (0) & 7 \\
\hline Total (54 species) & 1.45 & & \\
\hline \multicolumn{4}{|l|}{1991} \\
\hline 1 Theragra chalcogramma & 0.45 & $(43)$ & 14 \\
\hline 2 Gadus macrocephalus & 0.18 & (17) & 11 \\
\hline 3 Physiculus maximowiczi & 0.07 & (7) & 15 \\
\hline 4 Clupea pallasii & 0.07 & (7) & 5 \\
\hline 5 Brama japonica & 0.06 & (5) & 6 \\
\hline 6 Abyssicola macrochir & 0.06 & (5) & 11 \\
\hline 7 Etmopterus lucifer & 0.05 & (4) & 6 \\
\hline 8 Zestichthys tanakai & 0.04 & (4) & 4 \\
\hline 9 Sebastolobus macrochir & 0.01 & (1) & 2 \\
\hline 10 Malacocottus zonurus & 0.01 & (1) & 8 \\
\hline Total (54 species) & 0.99 & & \\
\hline
\end{tabular}



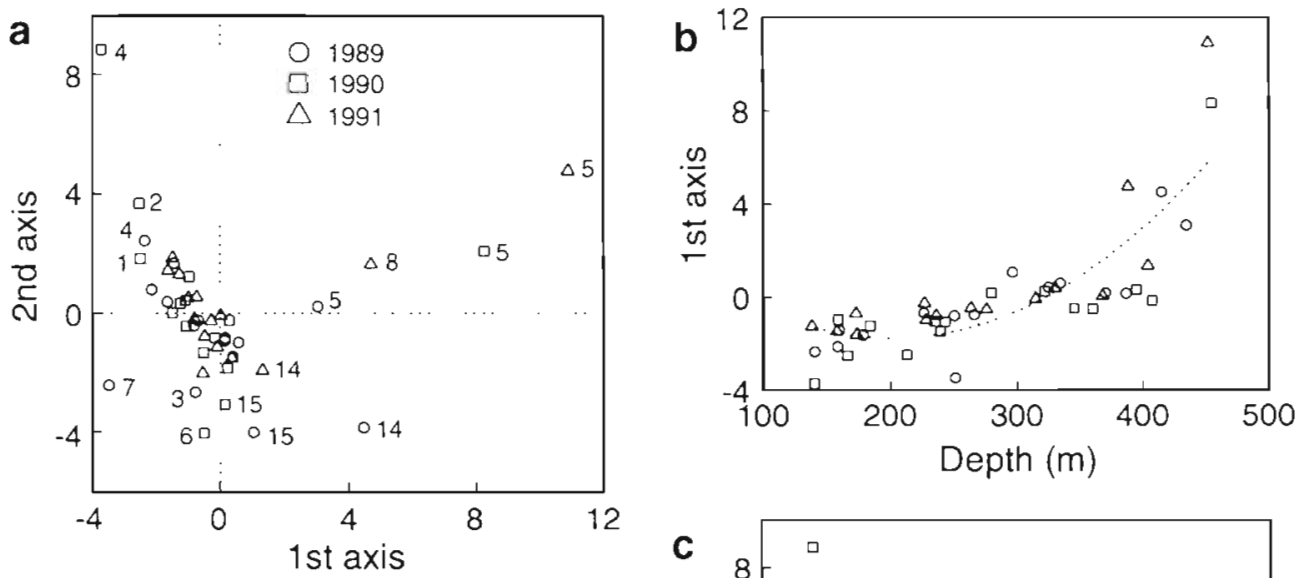

Fig. 4. Principal components analysis of 45 samples based on species composition. (a) 1st and 2 nd axes. Numbers near symbols indicate site number. (b, c) Relationships between the 2 axes and depth. Quadratic regressions are shown by dotted lines (see Table 2)

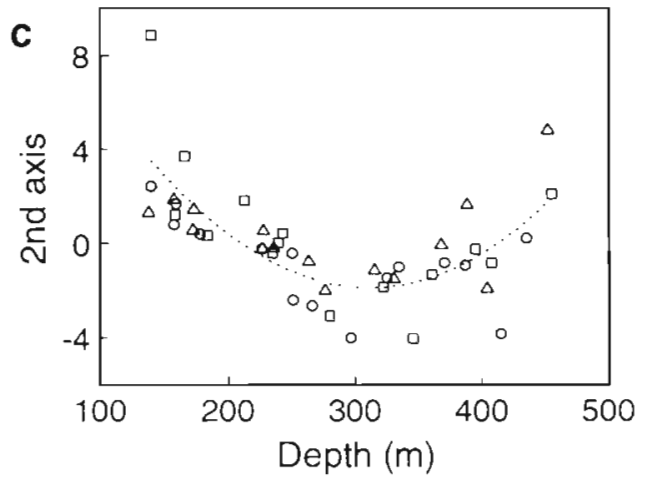

ponent was explained mostly by the proportion of the 2 dominant fishes.

Classification of the 15 sites was examined by cluster analysis based on species composition (Fig. 5). The clustering dendrogram was not identical annually since the catches varied at some sites. The sites where Theragra chalcogramma or Gadus macrocephalus were the dominant species were similar enough in species composition to be grouped in a large cluster. The shallowest site (Site 4) and the deepest site (Site 5) were isolated from the large cluster; dominant species were Liparis tanakai, Glossanodon semifasciatus and Physiculus maximowiczi at Site 4, and Laemonema longipes and Zestichthys tanakai at Site 5 (Table 3). The other 2 sites, Sites 2 and 8 , were secondarily isolated. The shallower Site 2 was separated from the large cluster in 1989 and 1990, but was grouped in it in 1991 when the dominant species was $P$. maximowiczi, but followed by $T$. chalcogramma. On the other hand, the deeper Site 8 was grouped in the large cluster in 1989 and 1990, but separated from it in 1991. A small separated cluster was recognized composed of 3 sites in each year, comprising the 2 sites which were common in every year (Sites 10 and 1) and another site which was different each year (Site 7, 13 or 3). Although the dominant species changed each year at these sites, T. chalcogramma and/or G. macrocephalus were abundant.

Annual persistence in species composition at each site is shown against depth in Fig. 6 . The persistence of presence/absence of species was 0.59 on the average with a range from 0.40 to 0.79 . It was high at the shallowest site (Site 4) and the deepest site (Site 5) The persistence of relative abundance of species was 0.54 on the average with a wider range from 0.18 to 0.89 .

Table 2. Linear and quadratic regressions of the 1 st and 2 nd principal components with depth. Significant correlations are shown by asterisks: " $p<0.05, \cdots p<0.01, \cdots p<0.001$. N: number of samples; $r$ : correlation coefficient; AlC: Akaike's information criterion. Regressions which better explain the correlation were determined by AIC and are shown by $r$ values in bold type

\begin{tabular}{|c|c|c|c|c|c|c|c|c|c|c|c|c|c|c|}
\hline \multirow[t]{3}{*}{ Axis } & \multirow{3}{*}{$\begin{array}{l}\text { Proportion } \\
\text { of variance } \\
\text { explained }\end{array}$} & \multirow{3}{*}{$\begin{array}{l}\text { Type of } \\
\text { regression }\end{array}$} & \multicolumn{12}{|c|}{ Regression with depth } \\
\hline & & & \multicolumn{3}{|c|}{1989} & \multicolumn{3}{|c|}{1990} & \multicolumn{3}{|c|}{1991} & \multicolumn{3}{|c|}{3 years } \\
\hline & & & $\mathrm{N}$ & $\mathrm{r}$ & AIC & $N$ & r & AIC & $N$ & r & AIC & $\mathrm{N}$ & $\mathrm{r}$ & AlC \\
\hline \multirow[t]{2}{*}{ 1st component } & 0.09 & Linear & 15 & $0.82 \cdots$ & 52.6 & 15 & $0.74 \cdots$ & 65.3 & 15 & $0.75 \cdots$ & 70.2 & 45 & $0.74 \cdots$ & 185.8 \\
\hline & & Quadratic & 15 & $0.85^{\cdots}$ & 51.8 & 15 & $0.81 \cdots$ & 63.0 & 15 & $0.89 \cdots$ & 60.8 & 45 & $0.82 \cdots$ & 172.3 \\
\hline \multirow[t]{2}{*}{ 2nd component } & 0.07 & Linear & 15 & $0.55^{\circ}$ & 60.6 & 15 & 0.50 & 76.6 & 15 & 0.02 & 64.8 & 45 & $0.36^{\circ}$ & 202.2 \\
\hline & & Quadratic & 15 & $0.77^{\cdot}$ & 54.4 & 15 & $0.86^{\cdots} \cdot$ & 61.9 & 15 & $0.78^{\cdot \cdot}$ & 52.7 & 45 & $0.73 \cdots$ & 175.1 \\
\hline
\end{tabular}



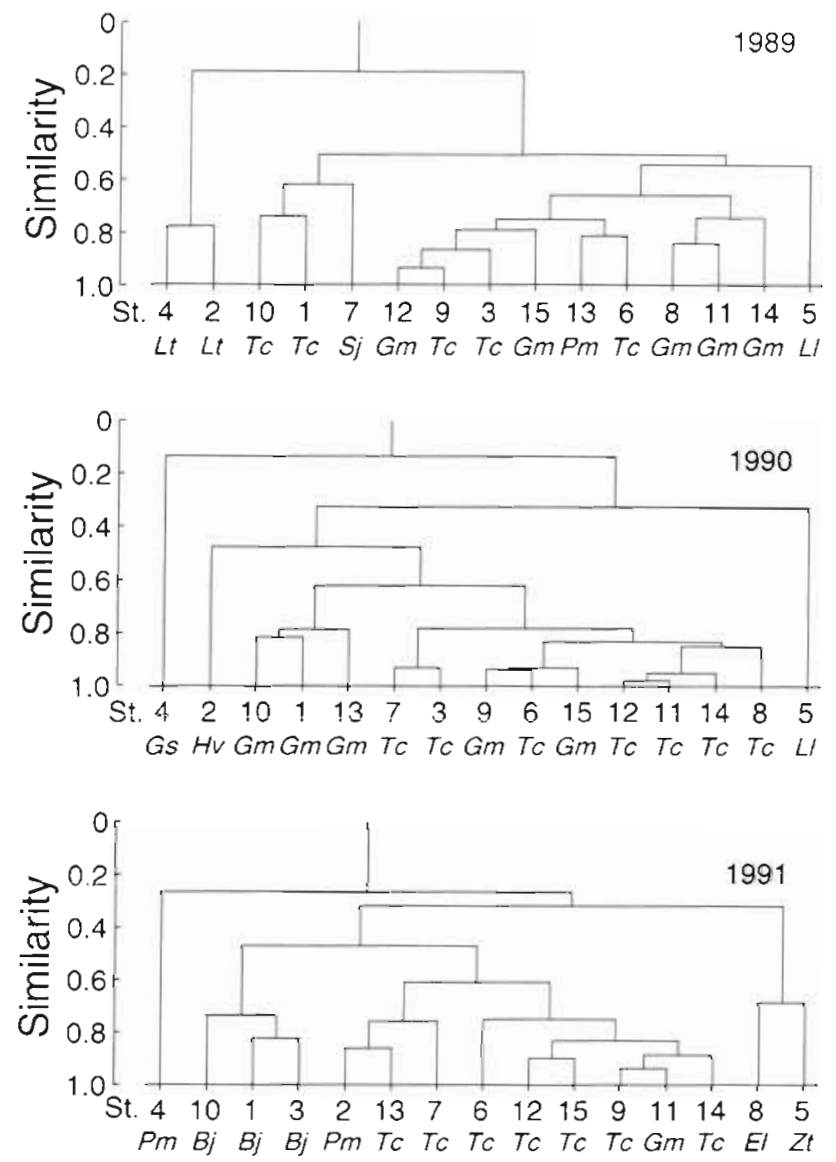

Fig. 5. Dendrogram showing classifications of 15 sites based on species composition. Dominant species at each site is denoted by abbreviations under the site number: Bj: Brama japonica; El: Etmopterus lucifer; Gm: Gadus macrocephalus; Gs: Glossanodon semifasciatus; Hv: Hemitripterus villosus; LI: Laemonema longipes; Lt: Liparis tanakai, Pm: Physiculus maximowiczi; Sj: Scomber japonicus; TC: Theragra chalcogramma; Zt: Zestichthys tanakai

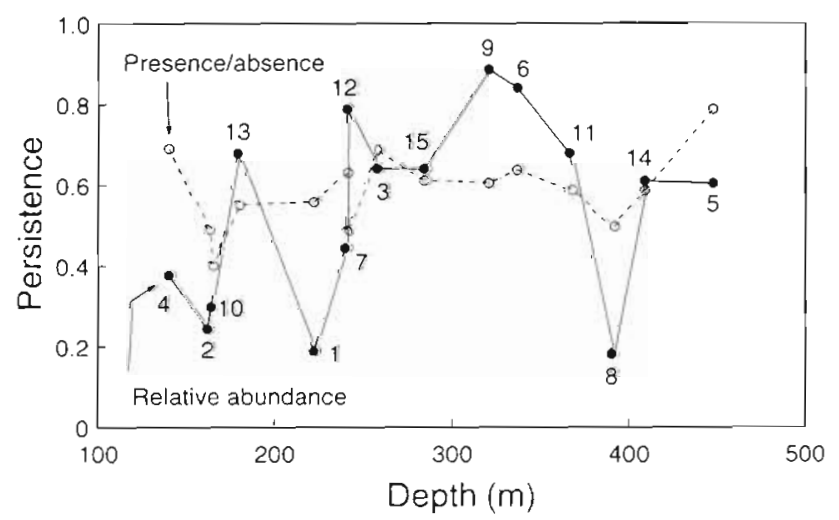

Fig. 6. Persistences in terms of presence/absence of species and relative abundance of species at each site, plotted against the average depth of each site. Numbers near solid circles denote site number
High values of persistence of relative abundance were found in an intermediate-depth zone (Sites 12, 3, 15, 9, 6 and 1.1; 241 to $366 \mathrm{~m}$ ). The 6 high-persistence sites were considered to be located in the center of the distribution of the uppermost slope community. Total catch at the 6 sites was different from the catches at the shallowest site and the deepest site (Table 3). In every year, Theragra chalcogramma and Gadus macrocephalus were constantly the first and the second most abundant in the total, respectively, and their percentages were very high. The persistences in the total catch were 0.65 and 0.93 for presence/absence and relative abundance, respectively.

\section{Depth patterns in abundance and species diversity}

Fish abundance and species diversity differed from site to site. On the average at 15 sites, biomass decreased from 1989 to 1991 although the number of species, the species diversity and equitability exhibited no significant annual differences (Table 4).

The depth-gradient characteristics of abundance and species diversity were examined using linear and quadratic regression statistics (Fig. 7, Table 5). For biomass and mean body weight per fish, significant regression was observed in all 3 years. Both linear and quadratic regressions were very significant $(p<0.001)$ for the pooled data from 3 years of biomass and of mean body weight. The fit in terms of biomass was better for the quadratic regression than for the linear regression, and biomass was maximum at ca $350 \mathrm{~m}$ deep. The fit in terms of mean body weight was better for the linear regression than for the quadratic regression, and body weight was greater in deeper waters. Other attributes also showed significant regressions with depth, at least for the pooled data from 3 years. Numerical density was higher at intermediate depths around $300 \mathrm{~m}(p<0.01)$. Equitability was lower at intermediate depths around $300 \mathrm{~m}(\mathrm{p}<0.001)$, and number of species increased with depth $(p<0.05)$. Species diversity was affected greater by equitability than by number of species, being lower at intermediate depths around $300 \mathrm{~m}(p<0.05)$. The biomass of the sites with high persistence (Sites 12,3,15,9,6 and 11) at the center depths of the uppermost slope was relatively high (Table 3 ), and the average species diversity was relatively low at 1.0,1.2 and 1.3 in 1989, 1990 and 1991, respectively.

\section{DISCUSSION}

Water depth is frequently the main gradient along which the faunal change is observed for offshore 
Table 3. The 5 most abundant species at the shallowest site (Site 4), total of the intermediate 6 sites (Sites $12,3,15,9,6$ and 11), and the deepest site (Site 5)

\begin{tabular}{|c|c|c|c|c|c|c|c|c|}
\hline \multirow{2}{*}{$\begin{array}{l}\text { Species } \\
\text { Site } \mathbf{4}(\mathbf{1 3 9} \text { to } \mathbf{1 4 1} \mathbf{m})\end{array}$} & \multicolumn{2}{|c|}{$\begin{array}{l}\text { Biomass } \\
\mathrm{kg} \text { per } \\
1000 \mathrm{~m}^{2}(\%)\end{array}$} & Species & \multicolumn{2}{|c|}{$\begin{array}{l}\text { Biomass } \\
\mathrm{kg} \mathrm{per} \\
1000 \mathrm{~m}^{2}(\%)\end{array}$} & Species & \multicolumn{2}{|c|}{$\begin{array}{l}\text { Biomass } \\
\text { kg per } \\
1000 \mathrm{~m}^{2}(\%)\end{array}$} \\
\hline & & & & & & & & \\
\hline Liparis tanakai & 0.13 & (34) & Glossanodon semifasciatus & $s \quad 0.26$ & (69) & Physiculus maximowiczi & 0.08 & $(50)$ \\
\hline Physiculus maximowiczi & 0.11 & (28) & Lipans tanakai & 0.03 & (9) & Liparis tanakai & 0.04 & (22) \\
\hline Oncorhynchus keta & 0.07 & (19) & Sphoeroides pachygaster & 0.02 & (6) & Hexagrammos otakii & 0.02 & $(12)$ \\
\hline Hexagrammos otakii & 0.04 & (10) & Physiculus maximowiczi & 0.02 & (6) & Hemitripterus villosus & 0.02 & (11) \\
\hline Hemitripterus villosus & 0.01 & (4) & Hemitripterus villosus & 0.01 & (3) & Dexistes rikuzenius & $<0.01$ & $(<1)$ \\
\hline Total (10 species) & 0.38 & & Total (11 species) & 0.38 & & Total (8 species) & 0.16 & \\
\hline \multicolumn{9}{|c|}{ Sites $12,3,15,9,6$ and $11(235$ to $371 \mathrm{~m})$} \\
\hline Theragra chalcogramma & 1.85 & $(47)$ & Theragra chalcogramma & 1.10 & (53) & Theragra chalcogramma & 0.90 & $(52)$ \\
\hline Gadus macrocephalus & 1.61 & $(41)$ & Gadus macrocephalus & 0.63 & (31) & Gadus macrocephalus & 0.34 & (19) \\
\hline Myctophidae spp. & 0.15 & (4) & Brama japonica & 0.15 & $(7)$ & Clupea pallasii & 0.17 & (10) \\
\hline Abyssicola macrochir & 0.13 & (3) & Abyssicola macrochir & 0.11 & (5) & Abyssicola macrochir & 0.12 & (7) \\
\hline Physiculus maximowiczi & 0.09 & (2) & Physiculus maximowiczi & 0.02 & (1) & Brama japonica & 0.09 & (5) \\
\hline Total (29 species) & 3.97 & & Total (31 species) & 2.06 & & Total (33 species) & 1.75 & \\
\hline \multicolumn{9}{|l|}{ Site $5(435$ to $455 \mathrm{~m})$} \\
\hline Laemonema longipes & 0.10 & $(18)$ & Laemonema longipes & 0.11 & $(20)$ & Zestichthys tanakai & 0.53 & $(46)$ \\
\hline Gadus macrocephalus & 0.09 & $(17)$ & Zestichthys tanakai & 0.10 & (18) & Sebastolobus macrochir & 0.20 & (18) \\
\hline Hippoglossoides dubius & 0.08 & $(14)$ & Physiculus maximowiczi & 0.10 & (18) & Etmopterus lucifer & 0.16 & (14) \\
\hline Theragra chalcogramma & 0.07 & (13) & Etmopterus lucifer & 0.07 & (12) & Physiculus maximowiczi & 0.07 & (6) \\
\hline Zestichthys tanakai & 0.07 & $(12)$ & Ruvettus pretiosus & 0.04 & (7) & Malacocottus zonurus & 0.06 & (6) \\
\hline Total (16 species) & 0.56 & & Total (20 species) & 0.56 & & Total (16 species) & 1.15 & \\
\hline
\end{tabular}

demersal fish communities (Haedrich et al. 1975, 1980, Pearcy et al. 1982, Bianchi 1991, 1992a, b, Merrett et al. 1991a, b, Merrett 1992, Fujita et al. 1993). In the present study, the environment changed mainly along the depth gradient, although the study sites were dispersed a little latitudinally (ca 37 to $38^{\circ} \mathrm{N}$ ) (Fig. 1), and we adopted depth for gradient analysis of the demersal fish community (Figs. 4, 6 \& 7). Many environmental factors change in association with the depth gradient (Carney et al. 1983), and it is difficult to specify the environmental factor responsible for faunal change with depth; water temperature (Fig. 3) was probably one of the most important gradients, partly because the distribution of the dominant fishes Theragra chalcogramma and Gadus macrocephalus was affected by the water temperature (Inada \& Murakami 1993).

The overall catch was characterized by large abundances of Theragra chalcogramma and Gadus macrocephalus (Table 1). The 2 most important axes of principal components analysis were related to depth (Fig. 4, Table 2), suggesting that the demersal fish fauna changed along the depth gradient, although the variance accounted for by the 2 axes was not the largest by far. The 2nd axis was explained by the dominant fishes, $T$. chalcogramma and $G$. macrocephalus, while the 1st axis was explained by subdominant species rather than the dominant ones, suggesting that the faunal change with depth was established not only by the dominant species but also by the other relatively minor species. The shallowest site (Site 4, ca $140 \mathrm{~m}$ ) and the deepest site (Site 5 , ca $445 \mathrm{~m}$ ) were quite disparate from the other sites in their species composition (Fig. 5, Table 3), and these 2 sites at least seemed to belong to the other types of community, i.e. the shelf community dominated by Liparis tanakai and Physiculus maximowiczi and the slope community dominated by Laemonema longipes.

Table 4. Biomass and species diversity indices (mean \pm SD of 15 sites), and their annual differences

\begin{tabular}{|llllc|}
\hline Index & 1989 & 1990 & 1991 & Difference \\
\hline Biomass $\left(\mathrm{kg} \text { per } 1000 \mathrm{~m}^{2}\right)^{\alpha}$ & $1.85 \pm 0.92$ & $1.18 \pm 0.67$ & $0.83 \pm 0.59$ & $\mathrm{p}<0.05$ \\
Number of species $(S)$ & $13.1 \pm 2.7$ & $13.6 \pm 3.1$ & $13.3 \pm 2.9$ & $\mathrm{~ns}$ \\
Species diversity $\left(H^{\prime}\right)$ & $1.26 \pm 0.54$ & $1.38 \pm 0.53$ & $1.39 \pm 0.32$ & $\mathrm{~ns}$ \\
Equitability $\left(J^{\prime}\right)$ & $0.49 \pm 0.20$ & $0.53 \pm 0.18$ & $0.55 \pm 0.14$ & $\mathrm{~ns}$ \\
& & \\
aMean and SD were calculated using $\log (x+1)$-transformed data & \\
\hline
\end{tabular}


$\log [\mathrm{D}]$
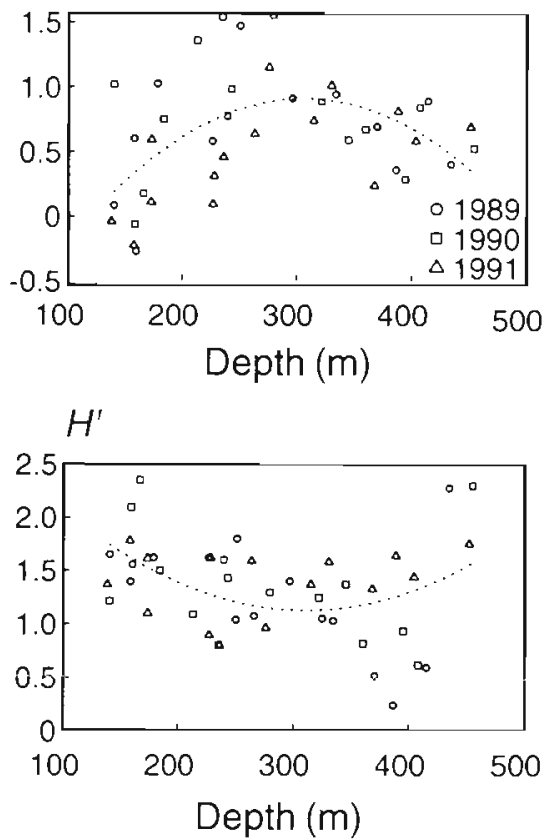

$\log [\mathrm{B}]$
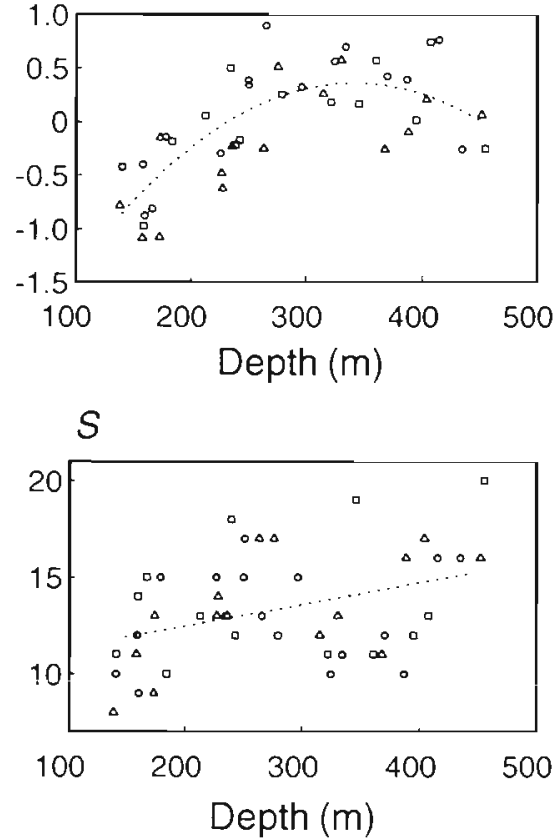

$\log [\mathrm{W}]$
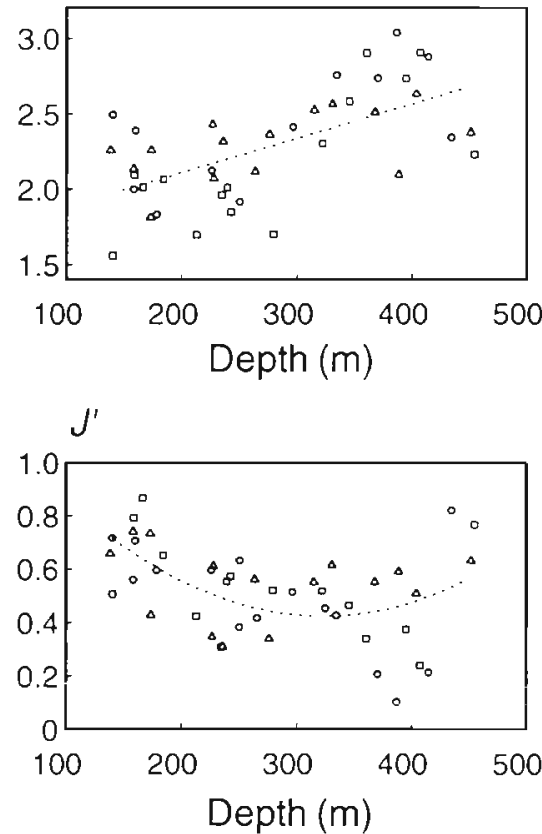

Fig. 7. Depth-gradient patterns of community characteristics. D: density (per $1000 \mathrm{~m}^{2}$ ); $\mathrm{B}$ : biomass ( $\mathrm{kg}$ per $\left.1000 \mathrm{~m}{ }^{2}\right)$; W: mean body weight per fish $(\mathrm{g})_{;} H^{\prime}$ : species diversity; $S$ : number of species; $J^{\prime}$ : equitability. Density, biomass and mean body weight per fish are shown on a logarithmic scale. Regressions are shown by dotted lines measured for the pooled data from 3 years (see Table 5)

Table 5. Depth-gradient trends of community characteristics. Linear and quadratic regressions of 6 attributes with depth were examined. Significant correlations shown by asterisks: $p<0.05, \cdots p<0.01, \cdots p<0.001$. N: number of samples; r: correlation coefficient; AIC: Akaike's information criterion. Regressions which better explain the correlation were determined by AIC and are shown by $r$ values in bold type

\begin{tabular}{|c|c|c|c|c|c|c|c|c|c|c|c|c|c|}
\hline \multirow{2}{*}{$\begin{array}{l}\text { Correlations between } \\
\text { depth }(\mathrm{m}) \text { and: }\end{array}$} & \multirow{2}{*}{$\begin{array}{l}\text { Type of } \\
\text { regression }\end{array}$} & \multicolumn{3}{|c|}{1989} & \multicolumn{3}{|c|}{1990} & \multicolumn{3}{|c|}{1991} & \multicolumn{3}{|c|}{3 years } \\
\hline & & N & $\mathrm{r}$ & $\mathrm{AlC}$ & $\mathrm{N}$ & r & $\mathrm{AIC}$ & $N$ & $r$ & AIC & $\mathrm{N}$ & r & AIC \\
\hline \multirow[t]{2}{*}{$\log \left[\right.$ Density $\left(\right.$ per $\left.\left.1000 \mathrm{~m}^{2}\right)\right]$} & Linear & 12 & 0.23 & 19.9 & 15 & 0.07 & 24.6 & 15 & $0.58^{\bullet}$ & 13.2 & 42 & 0.21 & 55.2 \\
\hline & Quadratic & 12 & 0.65 & 16.0 & 15 & 0.50 & 22.5 & 15 & $0.71^{\circ}$ & 10.8 & 42 & $0.51^{\cdots}$ & 46.2 \\
\hline \multirow[t]{2}{*}{$\log \left[\right.$ Biomass $\left(\mathrm{kg}\right.$ per $\left.\left.1000 \mathrm{~m}^{2}\right)\right]$} & Linear & 15 & $0.60^{\circ}$ & 21.3 & 15 & $0.59^{\circ}$ & 19.1 & 15 & $0.67 \cdots$ & 18.8 & 45 & $0.59 \cdots$ & $\cdot 54.2$ \\
\hline & Quadratic & 15 & $0.82 \cdots$ & 12.6 & 15 & $0.77 \cdots$ & 13.7 & 15 & $0.77^{\cdots}$ & 16.1 & 45 & $0.75 \cdots$ & $\cdot 37.9$ \\
\hline \multirow[t]{2}{*}{$\log [$ Mean weight $(g)$ per fish] } & Linear & 12 & $0.64^{\circ}$ & 10.0 & 15 & $0.74^{\circ}$ & 10.6 & 15 & $0.53^{\circ}$ & -2.5 & 42 & $0.62 \cdots$ & - 18.3 \\
\hline & Quadratic & 12 & 0.65 & 11.8 & 15 & $0.74 \cdots$ & 12.5 & 15 & 0.55 & -1.1 & 42 & $0.62 \cdots$ & $\cdot 20.3$ \\
\hline \multirow[t]{2}{*}{ Number of species $(S)$} & Line & 15 & 0.22 & 76.1 & 15 & 0.31 & 79.8 & 15 & $0.61^{\circ}$ & 72.2 & 45 & $0.38^{\circ}$ & 219.0 \\
\hline & Quac & 15 & 0.26 & 77.8 & 15 & 0.38 & 81.0 & 15 & $0.66^{\circ}$ & 72.4 & 45 & 0.38 & 220.9 \\
\hline \multirow[t]{2}{*}{ Species diversity $\left(H^{\prime}\right)$} & Linear & 15 & -0.4 .1 & 26.3 & 15 & -0.26 & 27.5 & 15 & 0.23 & 12.2 & 45 & -0.20 & 62.3 \\
\hline & Quadratir & 15 & 0.48 & 27.2 & 15 & 0.54 & 25.4 & 15 & 0.48 & 11.1 & 45 & $0.42^{\circ}$ & 57.3 \\
\hline \multirow[t]{2}{*}{ Equitability $\left(J^{\prime}\right)$} & Linear & 15 & -0.51 & -4.6 & 15 & -0.39 & -5.9 & 15 & -0.06 & -12.4 & 45 & $-0.34^{\circ}$ & -30.3 \\
\hline & Quadratic & 15 & 0.59 & -4.5 & 15 & 0.59 & -7.9 & 15 & 0.51 & -14.8 & 45 & $0.53 \cdots$ & -37.6 \\
\hline
\end{tabular}

Depth zonation and community classification studies should take temporal persistence into account, although until now most studies on the zonation of demersal fishes did not consider temporal variation (e.g Fujita et al. 1993). The trawl catches off Sendai Bay varied temporally, and the classification pattern of the sites based on species composition also varied tem- porally (Fig. 5). The species composition was, however, persistent at several sites, particularly in the intermediate-depth waters (ca 240 to $370 \mathrm{~m}$ ) between the shallower and deeper sites where the persistence was relatively low (Fig 6). These results delineated the depth-gradient structure of the uppermost slope community. The center depths, with persistent species 
composition dominated by Theragra chalcogramma and Gadus macrocephalus, were encompassed by the transition depths (ecotone) with low-persistence species composition including relatively more shallowwater or deep-water species. At the center depths, the temperature was 4 to $8^{\circ} \mathrm{C}$ and the salinity was lower than 34.0 (Fig 3). Depth boundaries of the 2 dominant fishes, $T$. chalcogramma and $G$. macrocephalus, were not located at a constant depth but varied within some depth range, and the biomass of these fishes was low near the boundaries where minor species coexisted at relatively high percentages. Such temporal variation in the depth boundaries and coexistence of diverse species reduced the persistence in species composition at the transition depths.

The uppermost slope community was characterized by high abundance and low species diversity (Fujita et al. 1993). The highest biomass and the lowest species diversity were observed at the center depths of the uppermost slope community (Fig. 7). Maximum numerical density was observed at ca $300 \mathrm{~m}$ or shallower, while maximum biomass was observed around $350 \mathrm{~m}$; the difference seemed due to the increase in mean weight per fish with depth. The trend of species diversity depended not on the number of species but on equitability, and equitability was minimum at ca $350 \mathrm{~m}$ or deeper, corresponding to the maximum biomass. The characteristics seemed to change gradually at the transition depths rather than to shift stepwise at a depth; transition depths should be considered when examining the depth zonation of demersal fishes.

The mean total biomass of demersal fishes was 2.5 to $1.0 \mathrm{~kg}$ per $1000 \mathrm{~m}^{2}$ in the study area (Table 1), and 4.0 to $1.8 \mathrm{~kg}$ per $1000 \mathrm{~m}^{2}$ at the intermediate depths considered as the depth center of the uppermost slope community (Table 3). Other otter trawl studies have reported biomass values on the upper slope of e.g. $1.3 \mathrm{~kg}$ per $1000 \mathrm{~m}^{2}$ at $250 \mathrm{~m}$ and $4.1 \mathrm{~kg}$ per $1000 \mathrm{~m}^{2}$ at $500 \mathrm{~m}$ in Rockall Trough (Gordon \& Bergstad 1992, their Fig. 6) that are almost equivalent to our data. Highest biomass of demersal fish communities around the uppermost slope has also been observed at other localities: the community dominated by Synagrops microlepis off Angola (Bianchi 1992a), and the community dominated by Chrolophthalmus albatrossis and Glossanodon semifasciatus off Tosa Bay (Horikawa 1993). These dominant species as well as Theragra chalcogramma and Gadus macrocephalus off Sendai Bay were commonly pelagic feeders; $S$. microlepis feed mainly on mesopelagic fishes (Bianchi 1992a), and C. albatrossis, G. semifasciatus (Horikawa 1993), $T$. chalcogramma and C. macrocephalus (Mikawa 1956, Hashimoto 1974, unpubl. data) on euphausiids. Pelagic organisms were quantitatively important food resources for demersal fish communities on the upper slope (see Houston \& Haedrich 1986, Fujita 1993). A euphausiid Euphausia pacifica is abundant not only in surface waters but also in deeper waters near the bottom in the study area (Odate 1991, J. Kodama pers. comm.), and the high biomass of the demersal fish community on the uppermost slope off Sendai Bay could be explained by the high availability of the euphausiid as food for the community.

A long-term study of a demersal fish community off Namibia (Macpherson \& Gordoa 1992) showed that the community stability was high although the biomass decreased. Macpherson \& Gordoa (1992) reported that the decrease in biomass was due to the high levels of fishing effort. Similar changes were also found off Sendai Bay; the total biomass decreased in the study period, but no significant change was observed for the average species diversity (Table 1) and relatively high persistence in species composition was observed at least at the intermediate depths (Fig. 6). The decrease in the total biomass was mainly due to the decrease of Gadus macrocephalus and Theragra chalcogramma. The decrease could probably be ascribed to the rise in water temperature (Inada \& Murakami 1993), although our short-term study failed to show a clear relationship between the abundances and the water temperature.

Persistence is an attribute of stability which is important for clarifying community organization (Pimm 1984), and it has been applied for freshwater fish community studies (see Grossman et al. 1990, Rahel 1990 and references therein). We used the 2 persistence indices as comparable, and communities could be viewed as having 2 different types of persistence: a presence/absence persistence and a relative-abundance persistence. Although we have only 3 years of data, the central part of the uppermost slope community seemed a relative-abundance persistent community, comprised of a few species which occurred constantly and dominantly and of minor species that were less abundant and occurred only occasionally. We considered only annual variation in this study, but the species composition and the bottom environments varied seasonally in the study area (unpubl. data). Horikawa (1993) confirmed a seasonal variation in the faunal depth boundary of demersal fishes off Tosa Bay. Seasonal changes should be also considered when examining the detailed temporal dynamics of the depthgradient structure of demersal fish communities.

Mean body weight per fish increased along the depth gradient (Fig. 7, Table 5) following Heincke's (1913) law (bigger-deeper trend) which is well known for many demersal fishes (e.g. Polloni et al. 1979, Horikawa et al. 1991, Macpherson \& Duarte 1991, Stefanescu et al. 1992, Horikawa 1993). The biggerdeeper trend in the study area resulted primarily from 
the 'within-species' trend (see Stefanescu et al. 1992) observed for the dominant fish species; body sizes of Theragra chalcogramma and Gadus macrocephalus were larger in deeper waters (unpubl, data). Ontogenetic habitat shifts are evident for many fishes (Helfman 1978, Werner \& Gilliam 1984, Horikawa et al. 1991) and could play an important role in producing depth zonation in demersal fishes.
Acknowledgements. We thank Akio Tamaki, Richard Brodeur, Kenji Saitoh and the anonymous reviewers for many helpful comments on the manuscript, and Orio Yamamura and Tsutomu Hattori for help in sampling at sea and in identification of fish species. The captains and crews of RV 'Shunyo Maru' and RV 'Wakataka Maru' assisted us in the sampling This work was partially supported by a grant (BCP95-IV-C-1) from the Ministry of Agriculture, Forestry and Fisheries.

Appendix. Species list of fishes collected off Sendai Bay, Japan

\begin{tabular}{|c|c|c|c|}
\hline Squalidae & Etmopterus lucifer & Trichiuridae & Benthodesmus tenuis \\
\hline Rajidae & Bathyraja sp. & Centrolophidae & Psenopsis anomala \\
\hline Chimaeridae & Hydrolagus barbouri & Nomeidae & Cubiceps squamiceps \\
\hline Clupeidae & Clupea pallasii & Stichaeidae & Stichaeus grigorjewi \\
\hline Engraulididae & Engraulis japonjcus & Cryptacanthodidae & Cryptacanthoides bergi \\
\hline Albulidae & Pterothrissus gissu & Zoarcidae & Lycodes caudimaculatus \\
\hline Nemichthyidae & Nemichthys scolopaceus & & Lycodes hubbsi \\
\hline Congridae & Conger myriaster & & Allolepis hollandi \\
\hline Salmonidae & Oncorhynchus keta & & Zestichthys tanakai \\
\hline Argentinidae & Glossanodon semifasciatus & Scorpaenidae & Sebastes minor \\
\hline Bathylagidae & Leurogrossus schmidti & & Sebastes baramenuke \\
\hline Gonostomatidae & $\begin{array}{l}\text { Ichthyococcus elegatus } \\
\text { Maurolicus muelleri }\end{array}$ & & $\begin{array}{l}\text { Sebastes sp. } \\
\text { Helicolenus hilgendorf }\end{array}$ \\
\hline Sternoptychidae & Sternoptyx diaphana & & Sebastolobus macrochir \\
\hline Chlorophthalmidae & Chlorophthalmus albatrossis & Hexagrammidae & Hexagrammos otakii \\
\hline Myctophidae & Myctophidae spp. ${ }^{\circ}$ & Ereuniidae & Marukawichthys ambulator \\
\hline Paralepididae & $\begin{array}{l}\text { Notolepis rissoi } \\
\text { Lestrolepis japonica }\end{array}$ & Cottidae & $\begin{array}{l}\text { Hemitripterus villosus } \\
\text { Icelus cataphractus }\end{array}$ \\
\hline Hemiramphidae & Hyporhamphus sp. & & Cottiusculus schmidti \\
\hline Moridae & $\begin{array}{l}\text { Physiculus maximowiczi } \\
\text { Laemonema longipes }\end{array}$ & & $\begin{array}{l}\text { Alcichthys alcicornis } \\
\text { Cottidae sp. }\end{array}$ \\
\hline Gadidae & $\begin{array}{l}\text { Gadus macrocephalus } \\
\text { Theragra chalcogramma }\end{array}$ & Psychrolutidae & $\begin{array}{l}\text { Dasycottus setiger } \\
\text { Malacocottus zonurus }\end{array}$ \\
\hline Macrouridae & $\begin{array}{l}\text { Nezumia propinqua } \\
\text { Abyssicola macrochir }\end{array}$ & Agonidae & $\begin{array}{l}\text { Occella kasawai } \\
\text { Podothecus sachi }\end{array}$ \\
\hline Berycidae & Beryx splendens & Liparididae & Liparis tessellatus \\
\hline Zeidae & $\begin{array}{l}\text { Cyttopsis rosea } \\
\text { Zeus faber } \\
\text { Zenopsis nebulosa }\end{array}$ & & $\begin{array}{l}\text { Liparis tanakai } \\
\text { Careproctus rastrinus } \\
\text { Crystallias matsushimae }\end{array}$ \\
\hline Percichthyidae & Synagrops japonicus & Pleuronectidae & Hippoglossoides dubius \\
\hline Carangidae & Naucrates ductor & & Hippoglossoides pinetorum \\
\hline Bramidae & Brama japonica & & Pleuronectes herzensteini \\
\hline Cepolidae & Cepola schlegeli & & Dexistes rikuzenius \\
\hline Scombridae & Scomber japonicus & & Clidoderma aspernimum \\
\hline \multirow[t]{4}{*}{ Gempylidae } & Nealotus tripes & & Microstomus achne \\
\hline & Promethichthys prometheus & Tetraodontidae & Takifugu porphyreus \\
\hline & $\begin{array}{l}\text { Gempylus serpens } \\
\text { Gempylus sp. }\end{array}$ & & Sphoeroides pachygaster \\
\hline & $\begin{array}{l}\text { Diplospinus multistriatus } \\
\text { Ruvettus pretiosus }\end{array}$ & \multicolumn{2}{|c|}{$\begin{array}{l}\text { a Mainly Diaphus watasei, but also including some other } \\
\text { unidentified species }\end{array}$} \\
\hline
\end{tabular}

\section{LITERATURE CITED}

Akaike, H. (1974). A new look at the statistical model identification. IEEE Trans. Automat. Contr. AC-19: 716-723

Bianchi, G. (1991). Demersal assemblages of the continental shelf and slope edge between the Gulf of Tehuantepec (Mexico) and the Gulf of Papagayo (Costa Rica). Mar. Ecol. Prog. Ser. 73: 121-140

Bianchi, G. (1992a). Demersal assemblages of the continental shelf and upper slope of Angola. Mar. Ecol. Prog. Ser. 81 . 101. -120

Bianchi, G. (1992b). Study of the demersal assemblages of the continental shelf and upper slope off Congo and Gabon. based on the trawl surveys of the RV 'Dr Fridtjof Nansen' Mar. Ecol. Prog. Ser. 85: 9-23

Blaber, S. J. M., Brewer, D. T., Salini, J. P., Kerr, J. (1990). Bımasses, catch rates and abundances of demersal fishes, particularly predators of prawns, in a tropical bay in the 
Gulf of Carpentaria, Australia. Mar. Biol. 107: 397-408

Carney, R. S., Haedrich, R. L., Rowe, G. T (1983). Zonation of fauna in the deep sea. In: Rowe, G. T (ed.) Deep-sea biology. John Wiley, New York, p. 371-398

Connell, J. H., Sousa, W. P. (1983). On the evidence needed to judge ecological stability or persistence. Am. Nat. 121. $789-824$

Coull, B. C., Fleeger, J. W. (1977). Long-term temporal variation and community dynamics of meiobenthic copepods. Ecology 58: 1136-1143

Fujita, T (1993). Community ecology of offshore demersal fish assemblages. Benthos Res. 44: 1-17 (in Japanese with English abstract and legends)

Fujita, T., Inada, T., Ishito, Y (1993). Density, bionass and community structure of demersal fishes off the Pacific coast of northeastern Japan. J. Oceanogr. 49: 211-229

Gordon, J. D. M., Bergstad, O. A. (1992). Species composition of demersal fish in the Rockall Trough, north-eastern Atlantic, as determined by different trawls. J. mar. biol. Ass. U.K. 72: $213-230$

Grossman, G. D., Dowd, J. F., Crawford, M. (1990). Assemblage stability in stream fishes: a review. Environ. Mgmt 14: 661-671

Haedrich, R. L., Rowe, G. T., Polloni, P. T (1975). Zonation and faunal composition of epibenthic populations of the continental slope south of New England. J. mar. Res. 33: $191-212$

Haedrich, R. L., Rowe, G. T., Polloni, P. T (1980). The megabenthic fauna in the deep sea south of New England, USA. Mar. Biol. 57: 165-179

Hashimoto, R. (1974). Investigation of feeding habits and variation of inhabiting depths with cod (Gadus macrocephalus) distributed on the northeastern fishing ground in Japan. Bull. Tohoku reg. Fish. Res. Lab. 33: 51-67 (in Japanese with English abstract)

Heincke, F. (1913). Untersuchungen über die Scholle Generalbericht. I. Schollenfischerei und Schommaßregeln. Vorläufige kurze Übersıcht über die wichtigsten Ergebnisse des Berichts. Rapp. P.-v. Réun Cons. perm. int. Explor. Mer 16: 1-70

Helfman, G. E. (1978). Patterns of community structure in fishes: summary and overview. Environ. Biol. Fish. 3: $129-148$

Horikawa, H. (1993). Bathymetric gradient analysis of demersal fish fauna across the continental shelf and slope of Tosa Bay, southwestern Japan. Doctoral dissertation, University of Tokyo

Horikawa, H., Toriyama, M., Kishida, S. (1991). Ontogenetic habitat shifts of demersal fishes along depth gradient. Rep. Fish. Res. Invest. Japan. Gov. 27: 61-78 (in Japanese with English abstract and legends)

Horn, H. S. (1966). Measurement of 'overlap' in comparative ecological studies. Am. Nat. 100: 419-424

Houston, K. A., Haedrich, R. L. (1986). Food habits and intestinal parasites of deep demersal fishes from the upper continental slope east of Newfoundland, northwest Atlantic Ocean. Mar. Biol. 92: 563-574

Inada, T., Murakami, M. (1993). Fluctuations of walleye pollock and Pacific cod resources and bottom temperature in the waters off the Tohoku region of Japan. Sci. Rep. Hokkaido Fish. Exp. Stn 42: 229-240 (in Japanese with English abstract and legends)

Macpherson, E., Duarte, C. M. (1991). Bathymetric trends in demersal fish size: is there a general relationship? Mar. Ecol. Prog. Ser. 71: 103-112

Macpherson, E., Gordoa, A. (1992). Trends in the demersal fish community off Namibia from 1983 to 1990. S. Afr. J. mar. Sci. 12: 635-649

May, J L., Blaber, S. J. M. (1989). Benthic and pelagic fish biomass of the upper continental slope off eastern Tasmania. Mar. Biol. 101: 11-25

Merrett, N. R. (1992). Demersal ichthyofaunal distribution in the abyssal eastern North Atlantic, with special reference to Coryphaenoides (Nematonurus) armatus (Macroundae) J. mar. biol Ass. U.K. 72: 5-24

Merrett, N. R., Gordon, J. D. M., Stehmann, M., Haedrich, R. L. (1991a). Deep demersal fish assemblage structure in the Porcupine Seabight (eastern North Atlantic): slope sampling by three different trawls compared. J. mar. biol. Ass. U.K. 71:329-358

Merrett, N. R., Haedrich, R. L., Gordon, J. D. M., Stehmann, M. (1991b). Deep demersal fish assemblage structure in the Porcupine Seabight (eastern North Atlantic): results of single warp trawling at lower slope to abyssal soundings J. mar. biol. Ass. U.K. 71. 359-373

Mikawa, M. (1956). Food. Demersal fishes in the north-eastern sea area along the Pacific coast of Japan. Tohoku Regional Fisheries Research Laboratory, Hachinohe (in Japanese)

Morisita, M. (1959). Measuring of interspecific association and similarity between communities. Mem. Fac. Scl Kyushu Unvv., Ser. E (Biol.) 3: 65-80

Odate, K. (1991). Fishery biology of the krill, Euphausia pacifica, in the northeastern coasts of Japan. Japan Fisheries Resource Conservation Association, Tokyo (in Japanese)

Pearcy, W. G., Stein, D. L., Carney, R. S. (1982). The deep-sea benthic fish fauna of the northeastern Pacific Ocean on Cascadia and Tufts Abyssal Plains and adjoining continental slopes. Biol. Oceanogr. 1: 375-428

Peterson, C. H. (1975). Stability of species and of community for the benthos of two lagoons. Ecology 56: 958-965

Pielou, E. C. (1969). An introduction to mathematical ecology Wiley-Interscience, New York

Pimm, S. L. (1984). The complexity and stability of ecosystems. Nature 307: 321-326

Polloni, P., Haedrich, R., Rowe, G., Clifford, C. H. (1979). The size-depth relationship in deep ocean animals. Int. Rev. ges. Hyrdrobiol. 64: 39-46

Rahel, F. J. (1990). The hierarchical nature of community persistence: a problem of scale. Am. Nat. 136: 328-344

Sale, P. F. (1980). The ecology of fishes on coral reefs Oceanogr. mar. Biol. A. Rev. 18: 367-421

Sokal, R. R., Rohlf, F. J. (1981). Biometry, 2nd edn. Freeman. New York

Sørensen, T. (1948). A method of establishing groups of equal amplitude in plant sociology based on similarity of species content. Biol. Skr. K. Danske Vidensk. Selsk. 5: 1-34

Stefanescu, C., Rucabado, J., Lloris, D. (1992). Depth-size trends in western Mediterranean demersal deep-sea fishes. Mar. Ecol. Prog. Ser. 81: 205-213

Tanaka, Y., Tarumi, T., Wakimoto, K. (1984). Handbook for statistical analysis by personal computers, II. Multivariate analysis. Kyoritu, Tokyo (in Japanese)

Werner, E. E. (1984). The mechanisms of species interactions and community organization in fish. In: Strong, D. R. Jr, Simberloff, D., Abele, L. G., Thistle, A. B. (eds.) Ecological communities: conceptual issues and the evidence. Princeton University Press, Princeton, NJ, p. 360-382

Werner, E. E. (1986). Species interactions in freshwater fish communities. In: Diamond, J., Case, T J. (eds.) Community ecology. Harper \& Row, New York, p. 344-358

Werner, E. E., Gilliam, J. F. (1984). The ontogenetic niche and species interactions in size-structured populations. A. Rev. Ecol. Syst. 15:393-425 